\title{
Kontaminasi Pestisida Organofosfat Dan Logam Berat pada Airtanah di Wilayah Pantai Utara Jawa Tengah dan Jawa Timur
}

\author{
B. Tyas Susanti', Chrisna Adhi Suryono², Baskoro Rochaddi2*, Irwani² \\ 'Pusat Studi Urban, Unika Soegijapranata Semarang \\ Jl. Pawiyatan Luhur Sel. IV No. 1, Bendan Duwur, Semarang, Jawa Tengah 50234 Indonesia \\ 2Fakultas Perikanan dan IImu Kelautan, Universitas Diponegoro \\ Jl. Prof Soedarto, SH., Tembalang, Semarang 50275 Indonesia \\ Email : rochaddi@ymail.com
}

\begin{abstract}
Organophosphate Pesticide and Heavy Metals Contamination at Groundwater in the North Coast Region of Central Java and East Java
\end{abstract}

\begin{abstract}
Groundwater is the main source of clean fresh water in coastal areas. Coastal cities development in many sectors often produces waste that pollutes groundwater, among others, in the form of pesticides and heavy metals. Chlorpyrifos, mercury and arsenic are contaminants that are toxic and endanger human health or the environment. The purpose of this study was to examine groundwater conditions against contamination of organophosphate pesticides, heavy metals $\mathrm{Hg}$ and As in the northern coastal areas of Central Java and East Java. Chlorpyrifos content was found in 4 sample locations with a concentration of $0.0004-0.0021 \mathrm{ppm}$. Hg content was found at 8 sample locations with a concentration of $0.004-0.321$ ppm and As was found at all locations (26) samples with a concentration of $0.102-0.505 \mathrm{ppm}$. The results of the analysis show that the incidence of pesticides and heavy metals in groundwater has anthropogenic sources due to agricultural, industrial or residential waste activities.
\end{abstract}

Keywords: groundwater; pesticide; heavy metals

\begin{abstract}
Abstrak
Airtanah merupakan sumber daya air tawar bersih yang utama di wilayah pesisir. Perkembangan kota-kota pesisir di banyak sektor seringkali menghasilkan limbah yang mencemari airtanah antara lain berupa pestisida dan logam berat. Khlorpirifos, merkuri dan arsen merupakan kontaminan yang bersifat toksik dan membahayakan kesehatan manusia ataupun lingkungan. Tujuan penelitian ini mengkaji kondisi airtanah terhadap kontaminasi pestisida organofosfat, logam berat $\mathrm{Hg}$ dan As di daerah pantai utara Jawa Tengah dan Jawa Timur. Kandungan khlorpirifos ditemukan di 4 lokasi sampel dengan konsentrasi 0,0004-0,0021 ppm. Kandungan Hg ditemukan pada 8 lokasi sampel dengan konsentrasi 0,004 - 0,321 ppm dan As ditemukan pada semua lokasi (26) sampel dengan konsentrasi 0,102-0,505 ppm. Hasil analisis menunjukkan kejadian pestisida dan logam berat pada airtanah bersumber antropogenik akibat kegiatan pertanian, industri atau limbah pemukiman.
\end{abstract}

Kata kunci: airtanah; pestisida; logam berat

\section{PENDAHULUAN}

Airtanah merupakan $30 \%$ dari sumber daya air tawar di dunia. Sembilan puluh tujuh persen dari air tawar yang potensial untuk digunakan manusia tersedia dalam airtanah dengan memperhitungkan $70 \%$ air tawar berupa sumber daya es (Morris et al., 2003). Oleh karena itu, konservasi airtanah menjadi kunci keberlanjutan pasokan air tawar bersih dunia dan perlu dikelola sebagaimana mestinya. Airtanah banyak digunakan di 
seluruh dunia untuk keperluan rumah tangga, industri, dan pertanian, dan baik daerah perkotaan maupun pedesaan bergantung pada sumber airtanah untuk memenuhi kebutuhan air penduduk (Singh et al., 2015). Airtanah dianggap sebagai sumber air minum yang sangat diperlukan, dan sepertiga populasi manusia bergantung pada airtanah untuk konsumsi air minum (Emenike et al, 2017). Namun, dengan kemajuan di sektor industri, sektor pertanian, dan tingginya pembuangan limbah, sumberdaya airtanah sering terkontaminasi bahan kimia berbahaya seperti pestisida atau logam berat. Aktivitas manusia yang intens, penambangan dan pengembangan industri telah diidentifikasi sebagai sumber pencemaran airtanah. Kondisi lebih buruk di daerah kering dan semi kering, di mana banyak penelitian telah menekankan perlunya pengelolaan dan perlindungan airtanah. (Ravindra et al., 2019), Polusi dari pemukiman pantai, pabrik, dan kegiatan pertanian melalui infiltrasi masuk ke dalam aliran airtanah (Eyles et al., 2013).

Hasil penelitian yang dilakukan oleh Rochaddi et al. (2018) menunjukan bahwa airtanah pada akuifer dangkal di pesir kota Semarang telah terkontaminasi oleh pestisida organoklorin dan logam berat Arsen. Penelitian sebelumnya yang dilakukan oleh Sabdono et al. (2008) pada tiga kota besar di wilayah pantai utara Jawa yaitu Jakarta, Semarang dan Surabaya menunjukkan parameter kimia-fisik dan tingkat kontaminasi pestisida organoklorin di sumur-sumur dangkal daerah perkotaan pesisir, Jawa. Hasilnya menunjukkan bahwa ada sedikit variasi di antara beberapa parameter kimia-fisik $(\mathrm{pH}$, suhu, salinitas). Pestisida yang ditemukan positif dalam sampel airtanah adalah heptaklor, aldrin, endosulfan, endrin dan $\mathrm{p} \mathrm{p-}$ DDT.

Penelitian saat ini banyak yang menunjukkan penggunaan insektisida yang berbahan aktif organofosfat lebih banyak dibandingkan organoklorin. Hal ini dapat dipahami karena insektisida berbahan aktif organoklorin sudah dilarang penggunaannya di lahan pertanian. Pada saat penelitian, terdapat beberapa produk pestisida dengan bahan aktif khlorpirifos yang dijual bebas di pasar tradisional. Khlorpirifos adalah jenis pestisida organofosfat yang banyak digunakan sebagai pengendalian hama di Indonesia. Residu khlorpirifos pada tanah atau produk pertanian juga banyak disampaikan oleh peneliti. Sulaeman et al. (2016) menemukan residu khlorpirifos dan enam jenis pestisida organofosfat lainnya dalam tanah sayuran kubis di Cisarua, Pacet dan Lembang di Jawa Barat. Harsanti et al. (2015) menyampaikan residu khlorpirifos dalam tanah dan produk bawang merah di Yogyakarta. Saiya et al. (2017) menemukan residu khlorpirifos pada sayuran kobis di Sulawesi Utara. Dewi et al. (2017) menemukan residu khlorpirifos dan profenofos pada komoditas cabai merah di Bali. Saat ini, pertumbuhan industrialisasi yang pesat telah menyebabkan peningkatan buangan limbah industri ke lingkungan. Akumulasi logam berat pada tanah, airtanah, sedimen, air permukaan dan udara memberikan dampak yang sangat berbahaya. Hal ini disebabkan karena logam berat tidak dapat dipecah oleh organisme menjadi bentuk tidak beracun sehingga memiliki efek jangka panjang pada ekosistem. Konsentrasi yang tinggi pada semua jenis logam berat memiliki efek merusak pada lingkungan (Cheng, 2003). Logam berat beracun seperti Mercuri $(\mathrm{Hg})$, Chrome (Cr), Tembaga (Cu), Zinc (Zn), timbal $(\mathrm{Pb})$, dan Kadmium (Cd) tidak memiliki peran biologis tetapi memiliki dampak toksisitas, mutagenik serta karsinogenik pada manusia dan organisme lainnya. Tujuan dari penelitian ini untuk mengetahui kondisi airtanah dangkal di wilayah pantai utara Jawa Tengah dan Jawa Timur, apakah masih baik atau sudah terkontaminasi oleh pestisida organofosfat dan atau logam berat merkuri dan arsen.

\section{MATERI DAN METODE}

Lokasi penelitian yang mewakili daerah pesisir dengan pemanfaatan lahan untuk industri, pertanian, dan daerah pemukiman, ditentukan dengan terlebih dahulu melakukan survei di sebagian wilayah pesisir Pantai Utara Jawa Tengah dan Jawa Timur masing-masing empat kota. Delapan kota tersebut adalah Semarang, Demak, Pati, Rembang, Lamongan, Gresik, Surabaya dan Sidoarjo seperti ditunjukkan Gambar 1. 
Pengambilan dua puluh enam sampel airtanah dari di masing-masing kota atau kabupaten sebagai berikut : Kota Semarang 5 lokasi, Kabupaten Demak 3 lokasi, Kabupaten Pati 3 lokasi, Kabupaten Rembang 4 lokasi, Kabupaten Lamongan 3 lokasi, Kota Gresik 3 lokasi, Kota Surabaya 3 lokasi dan Kabupaten Sidoarjo 2 lokasi. Analisis residu pestisida di dalam airtanah dilakukan di laboratorium Balai Penelitian Lingkungan Pertanian, Pati dengan menggunakan Gas Chromatography. Analisis logam berat di dalam airtanah dilakukan di laboratorium Univesitas Negeri Semarang dengan menggunakan ICP-OES (Inductively Coupled Plasma Optical Emission Spectrophotometer).

\section{HASIL DAN PEMBAHASAN}

Hasil analisis kandungan pestisida organofosfat khlorpirifos dan logam berat $\mathrm{Hg}$ serta As yang dilakukan terhadap 26 sampel airtanah ditunjukkan oleh grafik pada Gambar 2 dan 3. Secara statistik deskriptif hasil analisis konsentrasi khlorpirifos, $\mathrm{Hg}$ dan As dalam airtanah di daerah penelitian ditunjukkan oleh Tabel 1.

Konsentrasi khlorpirifos pada airtanah di daerah penelitian berkisar dari 0 sampai dengan 0,0021 ppm dengan nilai rata-rata (mean) 1,34615.10-4 ppm, median 0 dan standard deviasi (STDEV) 4,2983.10-4. Nilai STDEV yang lebih besar dari nilai rata-rata menunjukkan bahwa nilai rata-rata tersebut merupakan representasi yang jelek terhadap keseluruhan data atau berarti nilai rata-rata tidak dapat digunakan untuk mewakili konsentrasi khlorpirifos dalam airtanah di daerah penelitian. Hal ini juga ditunjukkan oleh nilai mediannya 0 yang merupakan nilai tengah dari kumpulan data konsentrasi

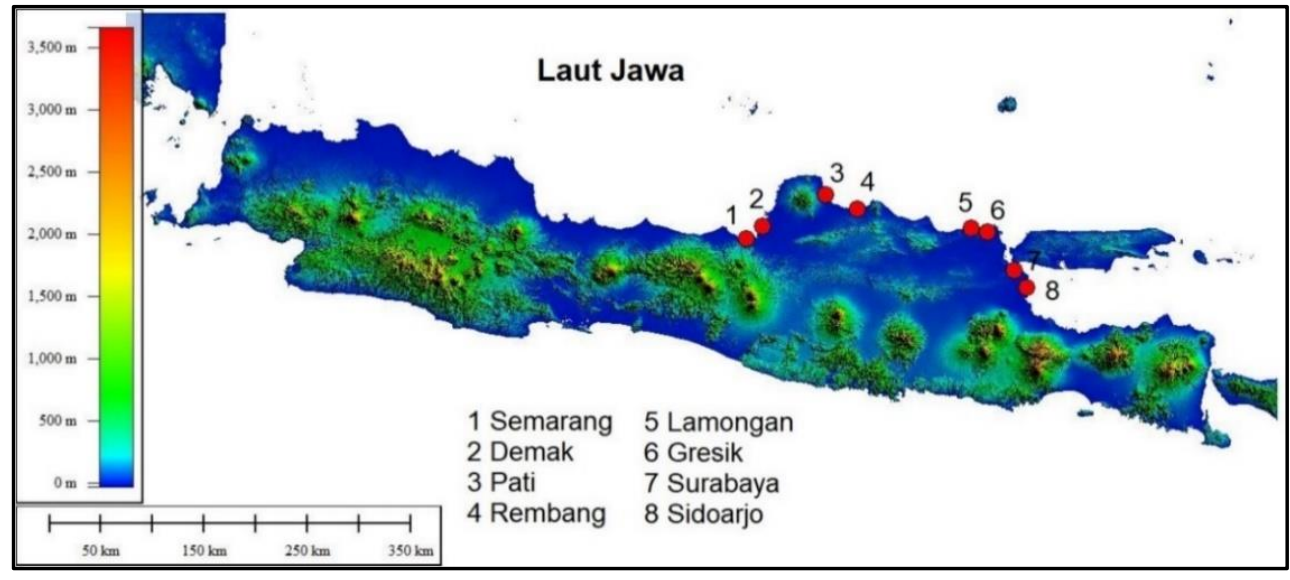

Gambar 1. Lokasi kota/kabupaten pengambilan sampel airtanah di wilayah pantai utara Jawa Tengah dan Jawa Timur.

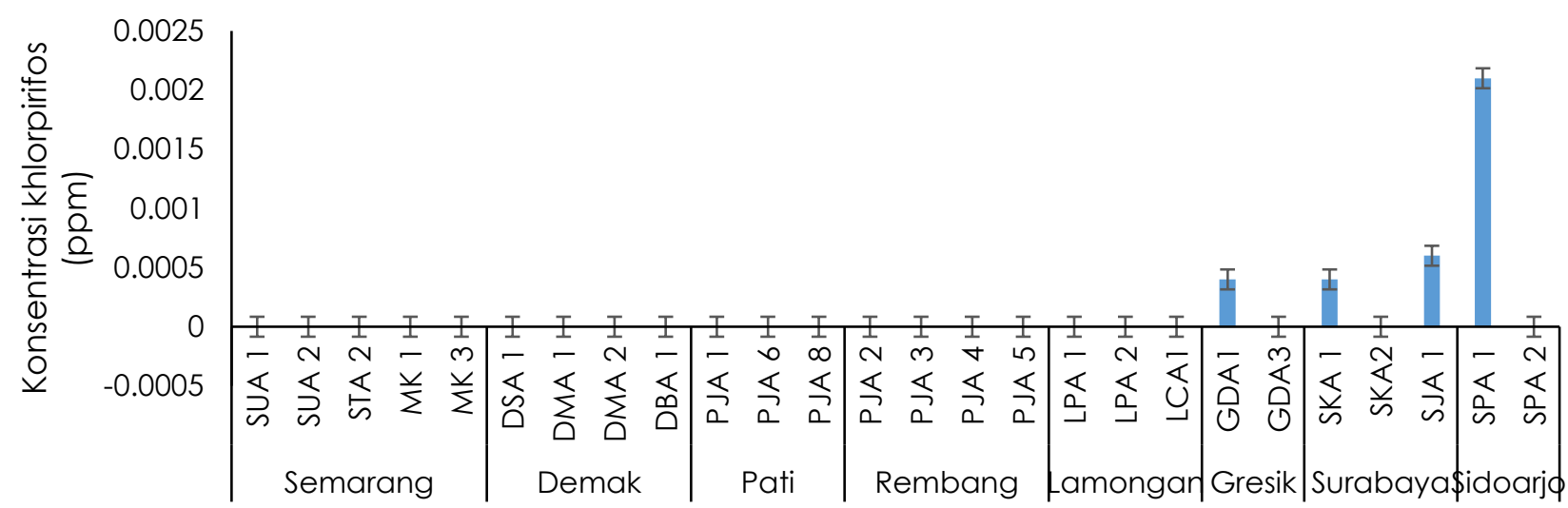

Gambar 2. Kandungan khlorpirifos dalam airtanah pada lokasi penelitian 


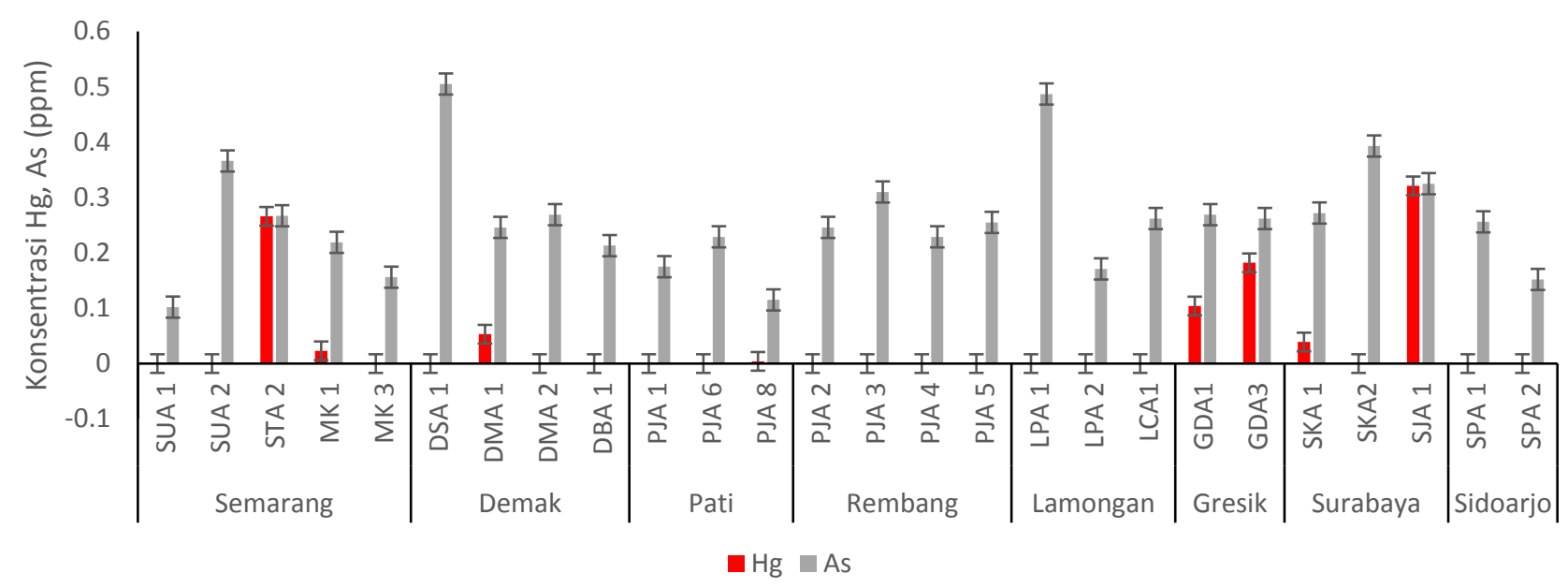

Gambar 3. Kandungan logam berat Hg dan As dalam airtanah di daerah penelitian.

Tabel 1. Statistik deskripstif kandungan khlorpirifos, $\mathrm{Hg}$ dan As dalam airtanah

\begin{tabular}{llllllll}
\hline & N total & Mean & S D & Sum & Min & Median & Maks \\
\hline Khlor & 26 & $1,34615 \mathrm{E}-4$ & $4,2983 \mathrm{E}-4$ & 0,0035 & 0 & 0 & 0,0021 \\
$\mathrm{Hg}$ & 26 & 0,03815 & 0,08597 & 0,992 & 0 & 0 & 0,321 \\
As & 26 & 0,25965 & 0,09745 & 6,751 & 0,102 & 0,2555 & 0,505 \\
\hline
\end{tabular}

khlorpirifos. Dapat diartikan konsentrasi khlorpirifos merupakan nilai setempat atau bersifat lokal yang tergantung pada kondisi di sekitar lokasi sampel. Airtanah yang dijumpai mengandung khlorpirifos di GDA 1, SKA 1, SJA 1 dan SPA 1 terdapat pada tanah yang bervariasi yaitu gleisol eutrik, alluvial gleik dan kambisol ustik dengan $\mathrm{pH}$ tanah agak asam sampai dengan agak alkalis dan tekstur halus, agak halus sampai sedang (BBSDLP, 2017). Konsentrasi khlorpirifos dalam airtanah ini tidak menunjukkan adanya hubungan terhadap jenis tanah, $\mathrm{pH}$ maupun tekstur tanah serta salinitas airtanah. Hal tersebut menunjukkan keberadaan khlorpirifos dalam airtanah hasil kegiatan antropogenik limbah kegiatan pertanian.

Akuifer airtanah dangkal di daerah penelitian umumnya adalah endapan alluvium yang tersusun dari sedimen klastik berukuran sedang hingga kasar yang dihasilkan dari proses pengendapan sungai (Supandjono et al, 1992). Ini berarti bahwa sistem aliran airtanah dangkal di daerah penelitian ini adalah sistem aliran antar butir.
Airtanah mengalir diantara pori-pori batuan penyusun akuifer, sehingga kecepatan aliran airtanah dan nilai konduktivitas hidrolik akuifer akan sangat tergantung pada ukuran dan keseragaman butiran tanah/ batuan yang membentuk akuifer dangkal. Secara umum, sampel airtanah diambil dari sumur dangkal yang terletak di daerah perumahan baik di Kota Gresik, Surabaya dan Sidoarjo. Konsentrasi pestisida khlorpirifos yang ditemukan di Sidoarjo paling tinggi dibandingkan di Surabaya dan Gresik. Hal ini dimungkinkan jika melihat penggunaan pestisida khlorpirifos sebagian besar di daerah pertanian, dan hasilnya sesuai jika melihat Kabupaten Sidoarjo memiliki lahan pertanian yang jauh lebih luas daripada Kota Gresik dan Surabaya. Dapat diartikan bahwa pestisida khlorpirifos yang ditemukan di sumur dangkal di daerah penelitian merupakan residu pertanian yang terlarut dan diinfiltrasi ke dalam tanah yang kemudian diangkut oleh aliran airtanah ke sumur dangkal di daerah perumahan yang merupakan titik pengambilan sampel airtanah. Berdasarkan dugaan bahwa pestisida khlorpirifos berasal 
dari residu pertanian, dicoba untuk membandingkan konsentrasi khlorpirifos yang ditemukan di sumur perumahan dengan jarak antara sumur dengan yang lahan pertanian terdekat di daerah di atasnya dalam sistem aliran airtanah. Berdasarkan asumsi konsentrasi awal khlorpirifos dalam sumber polutan dan laju aliran airtanah dangkal relatif sama, diperoleh bahwa semakin jauh jarak dari sumber polutan maka akan terjadi penurunan konsentrasi pestisida khlorpirifos (Rochaddi et al., 2019). Penurunan konsentrasi pestisida khlorpirifos ini dapat terjadi karena beberapa kemungkinan. Pertama, selama pergerakan dalam aliran airtanah, proses dispersi dan difusi terjadi, menghasilkan pengenceran konsentrasi khlorpirifos. Kedua, kemungkinan hidrolisis atau pestisida terurai di airtanah sehingga semakin lama konsentrasi khlorpirifos akan semakin kecil dan penyebab selanjutnya adalah kemungkinan pestisida ini terdegradasi oleh mikroba dalam aliran airtanah, sehingga konsentrasi juga akan berkurang. Ketiga, proses dapat berjalan sendiri atau secara bersamaan sehingga selama proses pengaliran airtanah dari sumber daerah pertanian ke sumur tempat pengambilan sampel berlangsung, konsentrasi yang tersisa semakin kecil.

Konsentrasi Hg pada airtanah di daerah penelitian berkisar dari 0 sampai dengan 0,321 ppm dengan nilai rata-rata (mean) 0,03815 ppm, median 0 dan standard deviasi (STDEV) 0,08597 . Nilai STDEV yang lebih besar dari nilai rata-rata menunjukkan bahwa nilai rata-rata merupakan representasi yang jelek terhadap keseluruhan data atau berarti nilai rata-rata tidak dapat digunakan untuk mewakili konsentrasi $\mathrm{Hg}$ dalam airtanah di daerah penelitian. Hal ini juga ditunjukkan oleh nilai mediannya 0 yang merupakan nilai tengah dari kumpulan data konsentrasi $\mathrm{Hg}$ dalam airtanah. Dapat diartikan konsentrasi $\mathrm{Hg}$ merupakan nilai setempat atau bersifat lokal yang tergantung pada kondisi di sekitar lokasi sampel tidak dapat digeneralisir ke lokasi lainnya. Merkuri $(\mathrm{Hg})$ telah lama diidentifikasi sebagai unsur yang merugikan, bahkan mematikan, bagi organisme hidup. Paparan bentuk anorganiknya, terutama dari uap unsur Hg (Fitzgerald dan Lamborg, 2007) dapat menyebabkan kerusakan pada sistem pernapasan, saraf, dan ginjal (Hutton, 1987; US
EPA, 2012). Merkuri terdeteksi dalam airtanah di Semarang pada STA 02 dan MK 01 dan di Demak pada DMA 01. Pati PJA 08, Gresik GDA 01 dan GDA 03, Surabaya SJA 01 dan SKA 01. Lokasi STA 02 dalam Kawasan Terboyo dan MK 01 dalam Kawasan Mangkang Semarang merupakan kawasan industri. Salah satu pemanfaatan lahan pada Terboyo merupakan Kawasan industri dengan basis kegiatan industri garmen, perakitan kendaraan bermotor, kimia, kayu, karet dan plastik, industri Logam Dasar, Barang Logam, Mesin dan Elektronik dan lain-lain (DPMPTSP Provinsi Jawa Tengah, 2019). Pemanfaatan lahan di daerah Mangkang juga cukup banyak dimanfaatkan sebagai Kawasan industri. Secara formal tercatat dua Kawasan industri besar di daerah tersebut serta cukup banyak kegiatan home industri dengan jenis kegiatan industri yang beragam. Airtanah Demak, pada lokasi DMA 01 yang terletak pada Kawasan Menco, Kecamatan Wedung secara umum di bagian atas (hulu) lokasi sampel merupakan lahan pertanian dan di sekitarnya pemukiman yang cukup padat dengan usaha perikanan. Lokasi PJA 08 di daerah Tayu Kabupaten Pati terletak pada area pemukiman yang di arah hulu dan sekitarnya berupa persawahan. Lokasi GDA 01 terletak pada lahan pertanian dan GDA 03 pada pemukiman di daerah Dalegan Gresik. Lokasi SKA 01 terletak pada area pemukiman Kec. Kedendeng, Surabaya dekat industri sedangkan SJA 01 pada daerah Jambangan, Surabaya berupa area pemukiman padat yang di sekitarnya terdapat kegiatan industry.

Airtanah yang dijumpai mengandung $\mathrm{Hg}$ di Semarang, Demak, Pati, Gresik dan Surabaya berada pada tanah yang bervariasi berupa alluvial gleik, gleisol eutrik, kambisol gleik dan kambisol ustik dengan $\mathrm{pH}$ tanah agak asam sampai dengan agak alkalis dan tekstur tanah agak halus sampai dengan sedang. Secara keseluruhan data konsentrasi $\mathrm{Hg}$ tidak menunjukkan hubungan dengan parameter tanah, tetapi jika konsentrasi $\mathrm{Hg}$ digolongkan dalam jenis tanah yang sama, pada alluvial gleik dan gleisol eutrik ada kecenderungan konsentrasi $\mathrm{Hg}$ mempunyai nilai yang lebih besar pada tekstur tanah yang lebih kasar atau lebih kecil pada tekstur yang lebih halus. Untuk melihat korelasi konsentrasi Hg terhadap MAT (Gambar 4 ). 
Berdasarkan Gambar 4, meskipun konsentrasi Hg tidak berkorelasi baik terhadap kedalaman MAT, gambar menunjukkan $\mathrm{Hg}$ dijumpai pada kedalaman $0,7 \mathrm{~m}$ sampai dengan $5 \mathrm{~m}$, dan paling banyak dijumpai pada kedalaman kurang dari $2 \mathrm{~m}$. Serupa dengan $\mathrm{Hg}$, konsentrasi As juga tidak menunjukkan korelasi yang baik terhadap parameter tanah jenis tanah, $\mathrm{pH}$ maupun tekstur tanah serta salinitas airtanah. Untuk konsentrasi arsen dalam airtanah dan hubungannya dengan kedalaman MAT ditunjukkan pada Gambar 5.

Arsen dijumpai pada semua lokasi pengambilan sampel airtanah di daerah penelitian. Meski tidak berkorelasi langsung dengan parameter tanah, berdasarkan plot

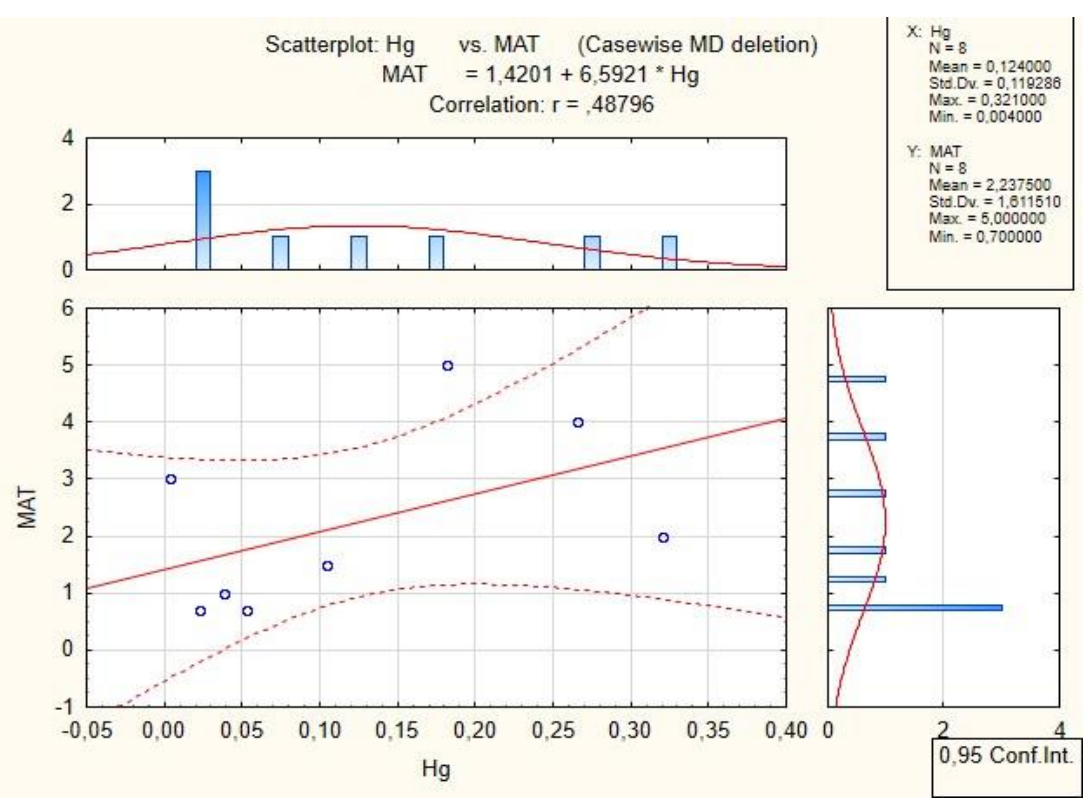

Gambar 4. Scatter plot konsentrasi Hg terhadap kedalaman MAT

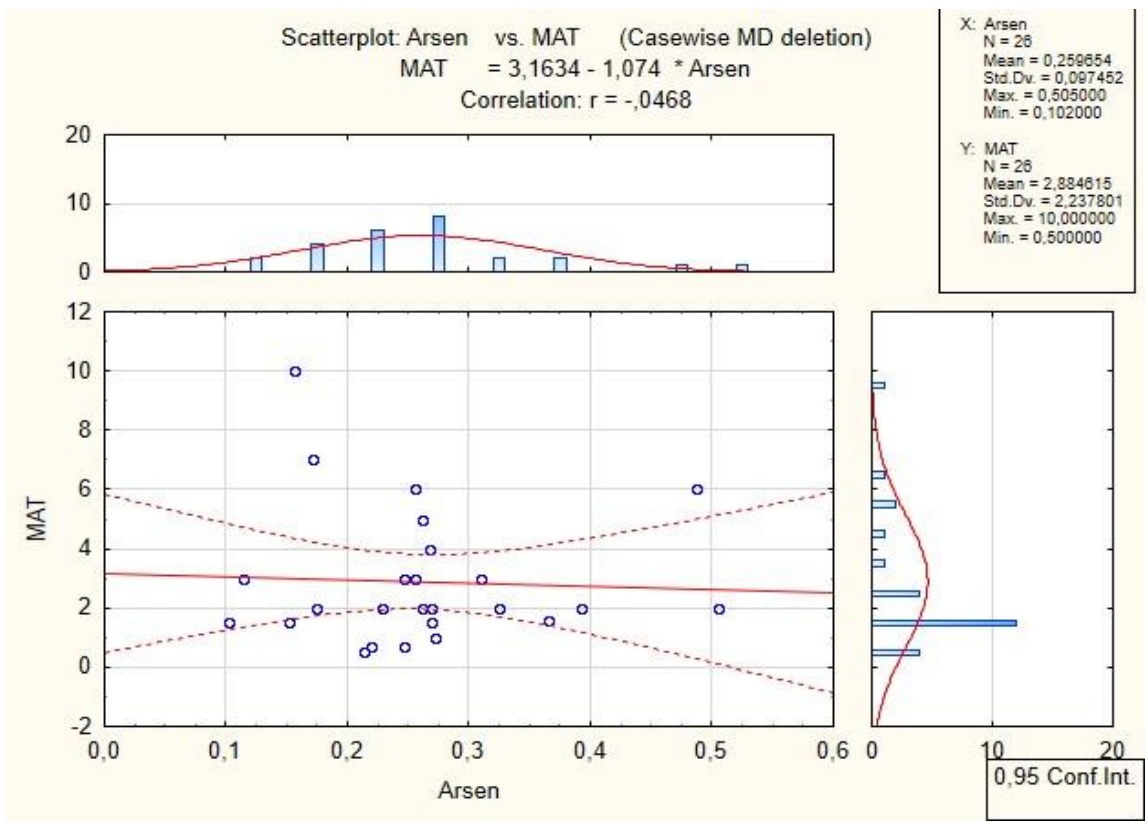

Gambar 5. Scatter plot konsentrasi As terhadap kedalaman MAT 
scatter antara konsentrasi arsen dan MAT lainnya dapat dijelaskan sebagai berikut: kejadian arsen paling banyak pada kisaran 0,2-0,3 ppm dengan nilai rata-rata 0,2597 ppm pada kedalaman MAT 0,5 m sampai dengan $6 \mathrm{~m}$. Konsentrasi arsen yang lebih tinggi dari 0,3 ppm paling tinggi frekuensinya pada kedalaman MAT berkisar 2 meter. Hal ini menunjukkan bahwa kejadian kontaminasi baik $\mathrm{Hg}$ maupun As lebih banyak dijumpai pada MAT yang lebih dangkal, hal tersebut dapat dipahami kontaminan yang berasal dari permukaan tanah tertransport ke dalam aliran airtanah akan selanjutnya mengikuti aliran airtanah yang lebih cenderung mengalir horisontal dibandingkan secara vertikal, hal ini dipengaruhi oleh nilai konduktivitas hidrolika (K) secara horizontal jauh lebih besar dibandingkan vertikal (Freeze dan Cherry, 1979).

Hasil analisis konsentrasi pestisida khlorpirifos, logam berat merkuri dan arsen yang dilakukan pada 26 sampel airtanah dari 8 kota wilayah pesisir dapat diartikan bahwa airtanah tersebut secara umum sudah tercemar. Pencemaran yang terjadi akibat kegiatan antropogenik berasal dari limbah kegiatan pertanian, industri dan pemukiman yang masuk ke dalam aliran airtanah dangkal sampai dijumpai pada sumur-sumur penduduk. Mengacu pada Peraturan Menteri Kesehatan Republik Indonesia nomor 492/Menkes/Per/IV/2010 tentang Persyaratan Kualitas Air Minum dengan batas ambang untuk untuk logam Arsen 0,01 ppm dan merkuri 0,001 ppm, maka kualitas airtanah dangkal pada lokasi yang menjadi sampel penelitian seluruhnya tidak memenuhi syarat sebagai air minum. Selanjutnya mengacu pada Peraturan Menteri Kesehatan nomor 32 tahun 2017, kualitas airtanah di daerah penelitian juga tidak memenuhi syarat Parameter Kimia dalam Standar Baku Mutu Kesehatan Lingkungan untuk Media Air untuk Keperluan Higiene Sanitasi yang mempunyai ambang batas pestisida total $0,1 \mathrm{mg} / \mathrm{l} ; \mathrm{Hg}$ 0,001 mg/l; As 0,05 mg/l.

\section{KESIMPULAN}

Kontaminasi pestisida, logam berat $\mathrm{Hg}$ dan As pada wilayah penelitian merupakan residu kegiatan antropogenik baik dari kegiatan pertanian, industri atau dari pemukiman. Kontaminasi pada airtanah dangkal terjadi pada kedalaman $0,7 \mathrm{~m}$ sampai dengan $10 \mathrm{~m}$ dengan kejadian lebih banyak terjadi pada kedalaman yang lebih dangkal atau kurang dari $3 \mathrm{~m}$.

\section{DAFTAR PUSTAKA}

Cheng, S. 2003. Heavy metal pollution in China: origin, pattern and control. Environmental Science and Pollution Research, 10(3):192-198.

Dewi I.S.U., Mahardika I.G., \& Antara, M., 2017. Residu pestisida golongan organofosfat komoditas buah cabai merah (Capsicum annuum L.) pada berbagai lama penyimpanan. Ecotrophic. 11 (1): 2017.3439

DPMPTSP Provinsi Jawa Tengah. 2019. http://web.dpmptsp.jatengprov.go.id /sarpras/1/33

Emenike, C.P., Tenebe, I.T., Omole, D.O., Ngene, B.U., Oniemayin, B.I., Maxwell, O. \& Onoka, B.I., 2017. Accessing safe drinking water in sub-Saharan Africa: issues and challenges in south-west Nigeria. Sustainable Cities and Society, 30:263e272. doi: 10.1016/j.scs.2017.01.005.

Eyles, N., Meriano, M. \& Chow-Fraser, P. 2013. Impacts of European settlement (1840present) in a Great Lake watershed and lagoon: Frenchman's Bay, Lake Ontario, Canada. Environ. Earth Sci., 68(8):22112228. doi: 10.1007/s12665-012-1904-8

Fitzgerald, W. \& Lamborg, C.H. 2007. Geochemistry of mercury in the environment.107-148. In: Environmental Geochemistry, V. 9; Lollar, B.S. (ed.), Oxford, Elsevier.

Freeze, R.A. \& Cherry, J.A. 1979. Groundwater. Prentice Hall, Inc. USA.

Harsanti E.S., Martono E., Sudibyakto H.A. \& Sugiharto E. 2015. Residu insektisida klorpirifos dalam tanah dan produk bawang merah Allium ascalonicum L., di sentra produksi bawang merah di Kabupaten Bantul, Yogyakarta. Ecolab, 9(1):01-46

Hutton, M. 1987. Human health concerns of lead, mercury, cadmium and arsenic, Chapter 6. 53-68. In Hutchinson, T.C. and Meema, K.M. (eds.) Lead, Mercury, 
Cadmium and Arsenic in the Environment, SCOPE, London, John Wiley and Sons, Ltd Morris, B.L., Lawrence, A.R.L., Chilton, P.J.C., Adams, B., Calow, R.C. \& Klinck, B.A., 2003. Groundwater and its susceptibility to degradation: a global assessment of the problem and options for management. 126pp. United Nations Environment Programme.

Peraturan Menteri Kesehatan nomor 32 tahun 2017, tentang Standar Baku Mutu Kesehatan Lingkungan dan Persyaratan Kesehatan Air untuk Keperluan Higiene Sanitasi, Kolam Renang, Solus per Aqua, dan Pemandian Umum.

Peraturan Menteri Kesehatan Republik Indonesia nomor 492/Menkes/Per/IV/2010 tentang Persyaratan Kualitas Air Minum

Ravindra, K., Suman, M. \& Pinnaka, V.L. 2019. Water uses, treatment, and sanitation practices in rural areas of Chandigarh and its relation with waterborne diseases. Environ. Sci. Poll. Res., 26:19512-19522

Rochaddi, B., Suryono, C.A., Atmodjo, W. \& Satriadi, A. 2018. Preliminary Study Contamination of Organochlorine Pesticide (Heptachlor) and Heavy Metal (Arsenic) in Shallow Groundwater Aquifer of Semarang Coastal Areas. IOP Conf. Series: Earth Environ. Sci., 116:012099. doi: 10.1088/1755-1315/116/1/012099.

Rochaddi, B., Sabdono, A. \& M. Zainuri. 2019. Preliminary study on the contamination of organophosphate pesticide (chlorpyrifos) in shallow coastal groundwater aquifer of Surabaya and Sidoarjo, East Java Indonesia. Conf. Series: Earth and
Environmental Science. 246:012079. doi: 10.1088/1755-1315/246/1/012079.

Sabdono, A., Rochaddi., B., Chrisna, A.S. \& Susanti, B.T., 2008. Persistent Organochlorine Residues in Household Wells of Java Coastal Urban Areas, Indonesia. J. App. Sci., 8(12):2318-2323.

Saiya, A., Gumolung, D., \& Howan D.H.O. 2017. Analisis residu klorpirifos dalam sayuran kubis dengan metode HPLC di beberapa pasar tradisional di Sulawesi Utara. Eksakta, 18(2):77-85.

Singh, S., Raju, N.J. \& Ramakrishna, C., 2015. Evaluation of groundwater quality and its suitability for domestic and irrigation use in parts of the Chandauli-Varanasi Region, Uttar Pradesh, India. J. Water Res. Prot., 7(7):572-587 doi: 10.4236/jwarp.2015.77046

Sulaeman, E., Ardiwinata, A.N. \& Yani, M. 2016. Eksplorasi Bakteri Pendegradasi Insektisida Klorpirifos di Tanah Sayuran Kubis di Jawa Barat. J. Tanah Iklim, 40(2):103-112

Supandjono, J.B., Hasan, K., Panggabean, H., \& Satria, D., 1992. Geological Map of Surabaya and Sapulu Quadrangle, Java" Geological Research and Development Center, Bandung.

United States Environmental Protection Agency (US EPA), Washington, D.C. 2012. National Emission Standards for Hazardous Air Pollutants from Coal- and Oil-Fired Electric Utility Steam Generating Units and Standards of Performance for Fossil-FuelFired Electric Utility, Industrial-CommercialInstitutional, and Small IndustrialCommercial-Institutional Steam Generating Units. Final rule.Federal Register, 77 FR9303 